\title{
Has Tom Brady Passed His Prime?
}

\author{
Paul M. Sommers \\ Department of Economics, Middlebury College, Middlebury, VT, USA \\ Email: psommers@middlebury.edu
}

How to cite this paper: Sommers, P.M. (2018) Has Tom Brady Passed His Prime? Open Journal of Statistics, 8, 831-836. https://doi.org/10.4236/ojs.2018.85054

Received: August 15, 2018

Accepted: September 25, 2018

Published: September 28, 2018

Copyright (C) 2018 by author and Scientific Research Publishing Inc. This work is licensed under the Creative Commons Attribution International License (CC BY 4.0).

http://creativecommons.org/licenses/by/4.0/

\begin{abstract}
The author examines the career passing statistics of Tom Brady (2000 to present), quarterback for the New England Patriots of the National Football League (NFL). In the categories of completions, attempts, completion percentage, passing yards, yards per attempt, touchdowns, and interceptions, there is no evidence of decline in per game averages since 2008 (when he tore his ACL) relative to his seven seasons as a starter before 2008. Moreover, there is no evidence of any statistically discernible performance change in his most recent four seasons as a starter relative to the three prior seasons. His consistency based on the coefficient of variation in games won is marginally better than his consistency in games lost, with one notable exception. Tom Brady's interceptions per game were more consistent during losses than they were during wins.
\end{abstract}

\section{Keywords}

National Football League, Tom Brady, 2-Sample $t$-Tests

\section{Introduction}

Since joining the New England Patriots of the National Football League (NFL) in 2000, quarterback Tom Brady has played in 253 games (through the 2017 regular season) with 251 starts. As a starter, he has passed for 66,107 yards. If we laid the distances of every one of his 5623 completed passes as a starter in that span end to end, they would cover close to 38 miles. ${ }^{1}$ The sixth round draftee in 2000 has won five Super Bowl rings (Super Bowl XXXVI, 2002; Super Bowl XXXVIII, 2004; Super Bowl XXXIX, 2005; Super Bowl XLIX, 2015; and Super Bowl LI, 2017). He has been selected to thirteen Pro Bowls and he has won three league MVP awards (2007, 2010 and 2017).

${ }^{1}$ In two games Tom Brady did not start (November 23, 2000 and September 23, 2001), he had six additional completed passes. 
Many people have written about Tom Brady, his success, lifestyle, and work ethic (see, for examples, Pierce [1], Mullins [2], Schalter [3], Sherman and Wedge [4], and Abdo [5]). But, no one has statistically examined how his averages have changed over the course of his career.

After sixteen seasons as a starter and currently at 41 years of age, ${ }^{2}$ one might wonder: has Tom Brady passed his prime? The natural dividing point in his career is the year 2008, when in the first game of the regular season, he tore his ACL. He missed the rest of the 2008 season and did not start his next game until September 14, 2009, the first game of the following season. How does Brady's performance since 2008 compare to his performance before 2008? Is there any evidence that his performance has declined in the last four seasons relative to the three seasons before 2014? Has Brady been more consistent in games won than in games lost?

\section{The Data}

Data on Tom Brady for each of the 253 games he started between 2001 and 2017 are from [6]. Variables of interest include completions, attempts, completion percentage, passing yards, yards per attempt, touchdowns, and interceptions per game. All variables are common metrics used to evaluate the performance of a quarterback. A completion is a forward pass that is caught in bounds by a receiver. An attempt is a quarterback's pass attempt. Completion percentage is the percentage of pass attempts completed. Passing yards is the number of yards gained by passing. Yards per attempt is the number of passing yards divided by the number of passing attempts. Touchdowns refer to the number of passes to a receiver who crosses the opponent's goal line after catching the football or who catches the football while in the opponent's end zone. Interceptions are passes caught by a defensive player (that is, a member of the opposing team), ending the offense's possession of the ball.

A common measure of relative variability or consistency is the coefficient of variation (hereafter abbreviated CV), namely, the standard deviation divided by the mean. The smaller the CV, that is, the smaller the standard deviation is relative to the mean, the more consistent Brady's performance.

For an example of the potential usefulness of the CV, in the women's gymnastics individual all-around competition at the 2012 Summer Olympics in London, Russian Aliya Mustafina and American Aly Raisman tied for third with 59.566 points apiece. However, Mustafina took the bronze after each gymnast's lowest score was dropped and their three remaining scores were combined. Mustifina's four scores were: Vault, 15.233; Uneven bars, 16.100; Balance beam, 13.633; and Floor, 14.600. Raisman's four scores were: Vault, 15.900; Uneven bars, 14.333; Balance beam, 14.200; and Floor, 15.133. Mustafina's CV was 0.06985 .

Raisman's CV was 0.05295. If, in the event of a tie, "consistency" had determined medal winners, then Raisman with the smaller $\mathrm{CV}$ would have been awarded the bronze medal in the all-around competition.

${ }^{2}$ Tom Brady's date of birth is August 3, 1977. 


\section{The Methodology}

As an athlete ages, his or her performance might be better, but fans may concede that it could be worse. Under these circumstances, in statistical analysis it is more appropriate to use a two-sided test. To determine whether there are statistically discernible differences (for better or worse) in Brady's performance before and after he tore his ACL in 2008, a series of two-sided $t$-tests were done, first, of the null hypothesis:

$$
H_{0}: \mu_{2008 \text { or Before }}=\mu_{\text {After } 2008}
$$

against the two-tailed alternative:

$$
H_{A}: \mu_{2008 \text { or Before }} \neq \mu_{\text {After } 2008}
$$

Moreover, Tom Brady's last seven seasons were divided into two shorter periods: 2011-2013 and 2014-2017. Under the null hypothesis, average performance each period was the same:

$$
H_{0}: \mu_{2011-2013}=\mu_{2014-2017}
$$

Under the two-tailed alternative, average performance had changed (either for better or worse):

$$
H_{A}: \mu_{2011-2013} \neq \mu_{2014-2017}
$$

Performance measures include: 1) completions, 2) attempts, 3) completion percentage, 4) passing yards, 5) yards per attempt, 6) touchdowns, and 7) interceptions per game. Finally, to assess Brady's consistency over his entire career, we will compare his $\mathrm{CV}$ in wins and losses for 1) through 7) above.

\section{The Results}

Table 1 summarizes the results of the two-tailed $t$-tests on the difference between means, before and after his ACL tear in 2008, an injury that cost him the remaining fifteen regular season games that year. The results reported in Table 1 indicate that the differences in means between 2001-2008 and 2009-2017 are all statistically discernible (using $\alpha=0.10$ ). Brady's numbers in the seven selected categories are uniformly better after 2008 than they were before. The most notable differences are more completions, more attempts, and more passing yards. Over the last nine seasons, Brady threw fewer interceptions per game compared to his first seven full seasons in the NFL.

If the physical talents of more senior players are on the wane, then one might expect Brady's averages between 2014 and 2017 to be lower than they were between 2011 and 2013. Surprisingly, the results in Table 2 show no statistical differences in his averages between the two periods. In three of the seven categories: completion percentage, touchdowns and interceptions per game, his averages were marginally (but not statistically) better in the more recent four-year period.

Table 3 shows the results of comparisons of Brady's sample mean 
Table 1. Differences before and after 2008.

\begin{tabular}{cccc}
\hline Variable & $\begin{array}{c}\text { Mean } \\
2001-2008^{\mathrm{a}} \\
\left(\mathrm{n}_{1}=111\right)\end{array}$ & $\begin{array}{c}\text { Mean } \\
2009-2017 \\
\left(\mathrm{n}_{2}=140\right)\end{array}$ & p-value on difference \\
\hline $\begin{array}{c}\text { Completions } \\
\text { Attempts }\end{array}$ & 20.676 & 23.771 & $<0.001$ \\
$\begin{array}{c}\text { Completion } \\
\text { percentage }\end{array}$ & 32.793 & 36.800 & $<0.001$ \\
Yards & 0.626 & 0.649 & 0.053 \\
Yards per & 237.784 & 283.664 & $<0.001$ \\
attempt & 7.269 & 7.819 & $\mathbf{0 . 0 2 1}$ \\
Touchdowns & 1.775 & 2.079 & 0.058 \\
Interceptions & 0.775 & 0.529 & $\mathbf{0 . 0 2 9}$ \\
\hline
\end{tabular}

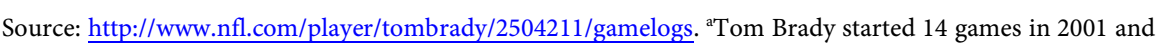
all 16 regular season games thereafter until 2008 when he tore his ACL in Game 1 of the regular season. Hence, $\mathrm{n}_{1}=111=14+(6 \times 16)+1$.

Table 2. Differences between 2011-2013 and 2014-2017.

\begin{tabular}{cccc}
\hline Variable & $\begin{array}{c}\text { Mean } \\
2011-2013 \\
\left(\mathrm{n}_{1}=48\right)\end{array}$ & $\begin{array}{c}\text { Mean } \\
2014-2017^{\mathrm{a}} \\
\left(\mathrm{n}_{2}=60\right)\end{array}$ & $p$-value on difference \\
\hline $\begin{array}{c}\text { Completions } \\
\text { Attempts }\end{array}$ & 24.625 & 24.183 & 0.699 \\
$\begin{array}{c}\text { Completion } \\
\text { percentage }\end{array}$ & 39.083 & 36.983 & 0.223 \\
Yards & 0.632 & 0.656 & 0.139 \\
$\begin{array}{c}\text { Yards per } \\
\text { attempt }\end{array}$ & 300.104 & 283.500 & 0.270 \\
Touchdowns & 7.770 & 7.760 & 0.977 \\
Interceptions & 2.042 & 2.150 & 0.632 \\
\end{tabular}

Source: http://www.nfl.com/player/tombrady/2504211/gamelogs. ${ }^{a}$ Tom Brady started all 16 regular season games in 2014 and 2015; he was suspended for the first four games of the 2016 NFL regular season for his role in "Deflategate," a football tampering scandal.

Table 3. Tom Brady's coefficients of variation (CV), selected variables, games won and lost, 2001-2017.

\begin{tabular}{|c|c|c|c|c|c|c|}
\hline \multirow[t]{2}{*}{ Variable } & \multicolumn{3}{|c|}{$\begin{array}{c}\text { Games } \\
\text { Won } \\
\left(\mathrm{n}_{1}=196\right)\end{array}$} & \multicolumn{3}{|c|}{$\begin{array}{c}\text { Games } \\
\text { Lost } \\
\left(\mathrm{n}_{2}=55\right)\end{array}$} \\
\hline & Mean & $\begin{array}{l}\text { Standard } \\
\text { deviation }\end{array}$ & $\mathrm{CV}$ & Mean & $\begin{array}{l}\text { Standard } \\
\text { deviation }\end{array}$ & $\mathrm{CV}$ \\
\hline Completions & 22.490 & 6.272 & 0.279 & 22.091 & 6.974 & 0.316 \\
\hline Attempts & 34.281 & 8.340 & 0.243 & 37.691 & 10.990 & 0.292 \\
\hline $\begin{array}{l}\text { Completion } \\
\text { percentage }\end{array}$ & 0.655 & 0.091 & 0.139 & 0.583 & 0.080 & 0.138 \\
\hline
\end{tabular}




\begin{tabular}{ccccccc} 
Continued & \multicolumn{7}{c}{0} & \\
\hline $\begin{array}{c}\text { Yards } \\
\text { Yards per }\end{array}$ & 269.755 & 79.091 & 0.293 & 240.636 & 87.891 & 0.365 \\
$\begin{array}{c}\text { attempt } \\
\text { Touchdowns }\end{array}$ & 7.920 & 1.805 & 0.228 & 6.349 & 1.582 & 0.249 \\
Interceptions & 0.449 & 1.253 & 0.585 & 1.236 & 1.018 & 0.823 \\
\hline
\end{tabular}

Source: http://www.nfl.com/player/tombrady/2504211/gamelogs.

$$
\bar{x}=\sum x_{i} / n
$$

sample standard deviation

$$
s=\sqrt{\frac{\sum\left(x_{i}-\bar{x}\right)^{2}}{n-1}}
$$

and $C V$

$$
C V=s / \bar{x}
$$

in games won and lost. Tom Brady averaged close to one more touchdown and one less interception per game in games won than in games lost. Surprisingly, Tom Brady's interceptions per game were more consistent during losses than they were during wins based on the CVs of the two distributions.

\section{Concluding Remarks}

Since joining the New England Patriots of the NFL in 2000, Tom Brady has become one of the greatest quarterbacks in NFL history. The results presented here show that his averages (completions, attempts, completion percentage, passing yards, yards per attempt, touchdowns, and interceptions per game) show no evidence of decline since 2008 (when he tore his ACL). In fact, they are clearly superior to what they were before 2008. And, as of this writing, over the last four seasons of his career (2014 through 2017), his averages have not declined relative to the three seasons before 2014. In games won, Brady is more consistent than in games lost, with one notable exception. Curiously, Brady's interceptions per game were more consistent during losses than they were during wins.

\section{Conflicts of Interest}

The author declares no conflicts of interest regarding the publication of this paper.

\section{References}

[1] Pierce, C.P. (2007) Moving the Chains: Tom Brady and the Pursuit of Everything. Farrar, Straus and Giroux.

[2] Mullins, S. (2014) Tom Brady 172 Success Facts-Everything You Need to Know about Tom Brady. Emereo Publishing Pty Ltd.

[3] Schalter, T. (2017) Tom Brady Will Be Bad Eventually. FiveThirtyEight. https://fivethirtyeight.com/features/tom-brady-will-be-bad-eventually/ 
[4] Sherman, C. and Wedge, D. (2018) The Inside Story of Tom Brady's Fight for Redemption. Little, Brown and Company.

[5] Abdo, K. (2018) Tom Brady. Abdo Group.

[6] Career statistics from NFL.com.

http://www.nfl.com/player/tombrady/2504211/gamelogs 